\title{
Prion: a janus-faced protein in cancer
}

\section{Editorial}

Prion is a key protein in the pathogenesis of neurodegenerative diseases so called transmissible spongiform encephalopathies (TSEs) and in cancer. The name of "prion" evolved from "Proteinaceous Infectious particle" which refers to two conformational isoforms of prion protein, endogenous cellular variant $\operatorname{PrP}^{\mathrm{c}}$, and its pathogen, misfolded and aggregated conformer, $\mathrm{PrP}^{\mathrm{Sc}} \cdot{ }^{1}$ Under some circumstances, physiological form of protein $\operatorname{PrP}^{\mathrm{c}}$ can transform to pathogen isoform, $\mathrm{PrP}^{\mathrm{Sc}}$ that is associated with TSEs including fatal familial insomnia, Creutzfeldt-Jakob disease and Kuru in humans. $\operatorname{PrP}^{\mathrm{c}}$ is a glycophosphatidylinositol-anchored cell surface glycoprotein and can interact with the cytosolic membrane bound organelles and with cytoskeleton. This protein highly accumulated in the central nervous system. However the transcripts of $\operatorname{PrP}^{\mathrm{c}}$ encoding gene (PRNP) can also be expressed in many other tissues including lymphoid organs. As a cell surface molecule, $\operatorname{PrP}^{c}$ has many interaction partners including transmembrane and secreted proteins. It also interact a variety of intracellular proteins. Based on the its potential binding partners, $\mathrm{PrP}^{\mathrm{c}}$ has been proposed to participate a broad array of cellular events such as cell death and survival, signal transduction, differentiation and cell adhesion. ${ }^{2-5}$ Due to transformation of $\operatorname{Pr}^{\mathrm{c}}$ into $\mathrm{PrP}^{\mathrm{Sc}}$, which leads to misfolding and induces apoptotic machinery thereby neurodegeneration (Gain of function effect), surveying the biological activity of $\mathrm{PrP}^{\mathrm{c}}$ seems to be critical for understanding the etiology and pathogenesis of prion diseases. ${ }^{6-8}$

Since the last 20 years, the concepts of cancer biology and cancer genetics have an important place in our life. Although ongoing clinical and laboratory researches have increased the survival rate and the quality of life in cancer patients, many cellular mechanisms still remain largely mysterious in cancer biology. Among these cellular events, programmed cell death types and the genes that control them have a unique significance because they have a profound effect on the malignant phenotype in tumorigenesis as well as in cancer treatment. Multidrug resistance (MDR) of tumor cells, characterized by decreased drug uptake, increased drug efflux and evasion of drug-induced apoptosis, is the major factor in the failure of cancer chemotherapy. Recent studies have indicated that the CD44 and $\mathrm{PrP}^{\mathrm{c}}$ coordinately increase the MDR phenotype in cancer stem cells by inducing the over expression of cell surface ATP-binding cassette transporters (Pgp-1) and, hence enhance the malignancy. ${ }^{9-11}$ Several intriguing lines of evidence indicating that $\mathrm{PrP}^{\mathrm{c}}$ over expression protect tumor cells from Bax-mediated apoptosis and/or autophagydependent cell death. Apparently, $\operatorname{PrP}^{\mathrm{c}}$ has a pivotal role in cancer prognosis as well as in TSE pathogenesis. More importantly, future progress in understanding the function of $\mathrm{PrP}^{\mathrm{c}}$, can be effective on the development and implementation of $\mathrm{PrP}^{\mathrm{c}}$-targeting novel therapeutic strategies.

\section{Acknowledgements}

None.
Volume 4 Issue 2 - 2017

\author{
Erdal Balcan \\ Department of Biology, Manisa Celal Bayar University, Turkey
}

Correspondence: Erdal Balcan, Department of Biology, Faculty of Arts and Science, Molecular Biology Section, Manisa Celal Bayar University, Șehit Prof. Dr. Ilhan Varank Campus 45047 Manisa,Turkey, Email erdal.balcan@cbu.edu.tr

Received: October 26, 2017 | Published: October 30, 2017

\section{Conflict of interest}

The author declares no conflict of interest.

\section{References}

1. Prusiner SB. Novel proteinaceous infectious particles cause scrapie. Science. 1982;216(4542):136-144.

2. Antony H, Wiegmans AP, Wei MQ, et al. Potential roles for prions and protein-only inheritance in cancer. Cancer Metastasis Rev. 2012;31(12):1-19.

3. Kovacs GG, Budka H. Prion diseases: from protein to cell pathology. Am J Pathol. 2008;172(3):555-565.

4. Turu M, Slevin M, Ethirajan P, et al. The normal cellular prion protein and its possible role in angiogenesis. Front Biosci. 2008;13:6491-6500.

5. Westergard L, Christensen HM, Harris DA. The cellular prion protein $(\operatorname{PrP}(\mathrm{C}))$ : its physiological function and role in disease. Biochim Biophys Acta. 2007;1772(6):629-644.

6. Martinou JC, Green DR. Breaking the mitochondrial barrier. Nat Rev Mol Cell Biol. 2001;2(1):63-67.

7. Roucou X, Giannopoulos PN, Zhang Y, et al. Cellular prion protein inhibits proapoptotic Bax conformational change in human neurons and in breast carcinoma MCF-7 cells. Cell Death Differ. 2005;12(7):783-795.

8. Martins VR, Beraldo FH, Hajj GN, et al. Prion protein: orchestrating neurotrophic activities. Curr Issues Mol Biol. 2010;12(2):63-86.

9. Du J, Pan Y, Shi Y, et al. Overexpression and significance of prion protein in gastric cancer and multidrug-resistant gastric carcinoma cell line SGC7901/ADR. Int J Cancer. 2005;113(2):213-220.

10. Pan Y, Zhao L, Liang J, et al. Cellular prion protein promotes invasion and metastasis of gastric cancer. FASEB J. 2006;20(11):1886-1888.

11. Cheng Y, Tao L, Xu J, et al. CD44/cellular prion protein interact in multidrug resistant breast cancer cells and correlate with responses to neoadjuvant chemotherapy in breast cancer patients. Mol Carcinog. 2004;53(9):686-697. 